Short communication

\title{
EFFECTS OF MOLSIDOMINE ON CORONARY ARTERY THROMBOSIS AND MYOCARDIAL ISCHEMIA IN ACUTE CANINE EXPERIMENTS
}

\author{
VOLKER B. FIEDLER \\ Department of Pharmacology, The University of Michigan Medical School, M 6322 Medical Science Building I, \\ Ann Arbor, $M I 48109$, U.S.A.
}

Received 12 May 1981, accepted 18 May 1981

V.B. FIEDLER, Effects of molsidomine on coronary artery thrombosis and myocardial ischemia in acute canine experiments, European J. Pharmacol. 73 (1981) 85-89.

Antithrombotic and hemodynamic properties of molsidomine $(0.10 \mathrm{mg} / \mathrm{kg}$ i.v. $)$ were evaluated in an in-vivo model of coronary artery thrombosis initiated by electrical stimulation for $6 \mathrm{~h}$. Molsidomine prolonged time to vessel occlusion and prevented heart rate and end-diastolic pressure increase and contractility decrease. Infarct size was smaller after drug treatment related either to left ventricle $(P<0.02)$ or to vessel area-at-risk $(P<0.01)$. It is suggested that molsidomine has antithrombotic effects which might prevent acute coronary infarction.

Coronary thrombosis Molsidomine Myocardial infarct size

\section{Introduction}

Molsidomine is a new antianginal agent with effects on hemodynamics (Fiedler and Scholtholt, 1978) and on the venous side of the circulation (Holtz et al., 1978). In patients, the drug has been shown to be effective in the treatment of angina pectoris by a nitroglycerin-like mode of action but of substantially longer duration (Majid et al., 1980). Recent studies (Slany et al., 1981) in patients with coronary artery disease suggested that molsidomine might decrease platelet reactivity as assessed by in-vitro aggregometry. The drug also produced a dilatation of large coronary vessels in the isolated blood perfused canine heart (Schaper, unpublished observations) which might serve as an important mechanism for improving coronary flow to an ischemic region of the myocardium via collateral vessels. The potential of molsidomine in this respect would be enhanced if the drug prevented in-vivo platelet aggregation in response to vascular injury. Accordingly, the present study was designed to determine the effects of molsidmone on protection of the acutely ischemic canine myocardium and on in-vivo platelet reactivity.

\section{Materials and methods}

14 adult mongrel dogs of either sex weighing between 18 to $26 \mathrm{~kg}$ were randomly assigned to groups receiving either molsidomine ( 8 dogs) or saline (6 dogs), anesthetized with i.v. pentobarbital sodium $(30 \mathrm{mg} / \mathrm{kg})$, incubated and placed on positive pressure respiration (Harvard respirator, model 607) using room air. Body temperature was regulated at $37 \pm$ $1^{\circ} \mathrm{C}$ by a heating pad. Aortic blood pressure was measured by a cannula positioned in the descending aorta via the right femoral artery using a Statham pressure transducer (model P $23 \mathrm{Db}$ ). A peripheral vein was catheterized for compound administration. Left ventricular systolic and end-diastolic pressure was determined by means of a microtip pressure transducer (Millar Instr., model PC-350) introduced into the left ventricle via the exposed left 
carotid artery. Heart rate was obtained from the electrocardiogram (limb lead II). Contractility was obtained by continuous computer differentiation of left ventricular pressure as $\mathrm{d} P / \mathrm{d} t$. The sum of ST-segment elevations was obtained from 5 single measurements at the determination times. A thoracotomy was performed at the fifth left intercostal space, the lungs retracted and the heart was suspended in a pericardial cradle. A calibrated flow probe was positioned around the left circumflex coronary artery (LCX) distal to the atrial branch and proximal to its first descending branch for measurement of phasic and mean LCX flow by a flowmeter (Carolina Instr.). Coronary vascular resistance was obtained by dividing mean aortic pressure by mean LCX flow. A silk snare was placed around the vessel distal to the probe. To aid in the insertion of the LCX stimulating electrode, the tip of a 25-gauge hypodermic needle was secured to the leading end of a 28-gauge teflon coated silver wire (Romson et al., 1980b). This electrode was inserted through the wall of the LCX so that the tip of the electrode $(2-3 \mathrm{~mm})$ was in contact with the intimal lining of the vessel. The circuit was completed by suturing a disc electrode to a subcutaneous region of the chest wall. Hemodynamic variables were recorded on a Grass model 7 polygraph.

\subsection{Experimental design}

After basal hemodynamic measurements were recorded either molsidomine $(0.10 \mathrm{mg} /$ $\mathrm{kg}$ ) or saline were intravenously administered. 15 to 20 min later (Holtz et al., 1978) electrical stimulation of the LCX was initiated at $150 \mu \mathrm{A}$ via the implanted silver wire electrode. Stimulation was continued for $6 \mathrm{~h}$ using a $250000 \Omega$ potentiometer, a $9 \mathrm{~V}$ nickelcadmium battery, and a digital ammeter. Recordings were done every $15 \mathrm{~min}$ at 25 $\mathrm{mm} / \mathrm{sec}$.

\subsection{Quantification of infarct size and throm- bus weight}

Following final recordings at completion of the $6 \mathrm{~h}$ stimulation, the animal was sacrificed by an overdosage of anesthetic, the heart was electrically fibrillated and rapidly removed for post-mortem quantification of infarct size (Romson et al., 1980a). To this end, cannulae were inserted into the vessel distal to the site of LCX occlusion and into the aortic root above the coronary ostia. The LCX coronary bed was perfused with $1.5 \%$ triphenyltetrazoliumchloride (TTC) in $20 \mathrm{mM}$ potassium phosphate buffer. The aorta was perfused in a retrograde manner with $0.5 \%$ Evans blue. Both solutions were perfused at a constant pressure of $100 \mathrm{mmHg}$ for $20 \mathrm{~min}$. The heart was then sliced into $1.0-\mathrm{cm}$ thick sections. The area of the left ventricle at risk was demarcated by lack of reddish staining of the tissue when perfused with TTC. The areaat-risk, in addition to the regions of infracted myocardium were excised from the left ventricle and weighed. Thus, the extent of infarction was expressed as a percentage of both total left ventricle and the area of myocardium at risk. The previously occluded LCX was dissected free of surrounding tissue and opened lengthwise. Adhering thrombotic material was removed from the intimal surface of the LCX to determine thrombus wet weight.

\subsection{Statistical analysis}

Statistical analysis of results on hemodynamics was made by use of Student's $t$-test for paired samples and analysis of variance followed by Dunnett's modification of the $t$-test. Infarct sizes were compared by use of the two-by-two chi square analysis. All data are expressed as mean \pm standard error of the mean (S.E.M.). Differences between control and drug-treated values were considered significant when $\mathrm{P}<0.05$. 


\section{Results}

The results shown in table 1 summarize the effects of molsidomine on myocardial hemodynamics during LCX stimulation. $30 \mathrm{~min}$ after drug administration mean aortic pressure, left ventricular end-diastolic pressure, and mean LCX coronary blood flow decreased significantly. Heart rate and contractility $(\mathrm{d} P /$ $\mathrm{d} t_{\max }$ ) remained unaffected by the drug. After occlusion of the LCX, mean aortic pressure decreased in both groups. In the saline group, heart rate and end-diastolic pressure increased significantly while contractility fell. As a sign of ischemia the sum of ST-segments elevated significantly in the saline controls until completion of the experiments, but no changes occurred in the molsidomine-treated group. LCX coronary blood flow fell to zero after $3.1 \pm 0.4 \mathrm{~h}$ (table 2 ) of electrical stimulation in the controls but after $3.8 \pm 0.3 \mathrm{~h}$ in the molsidomine animals. Thus,

\section{TABLE 1}

Effects of molsidomine on myocardial hemodynamics.

\begin{tabular}{|c|c|c|c|c|c|c|}
\hline Parameter & Compound & Control & $30 \mathrm{~min}$ & $3 \mathbf{h}$ & $4 \mathrm{~h}$ & $6 \mathrm{~h}$ \\
\hline $\begin{array}{l}\text { Mean aortic pressure } \\
(\mathrm{mmHg})\end{array}$ & $\begin{array}{l}\mathrm{M} \\
\mathrm{NaCl}\end{array}$ & $\begin{array}{l}121 \\
\pm 5 b \\
118 \\
\pm 3\end{array}$ & $\begin{array}{l}81 \\
\pm 4 \\
117 \\
\pm 5\end{array}$ & $\begin{array}{l}118 \\
\pm 5 \\
119 \\
\pm 4\end{array}$ & $\begin{array}{l}97 \\
\pm 4 \\
93 \\
\pm 6\end{array}$ & $\begin{array}{l}118 \\
\pm 4 \\
116 \\
\pm 3\end{array}$ \\
\hline Hear rate $\left(\min ^{-1}\right)$ & $\begin{array}{l}\mathrm{M} \\
\mathrm{NaCl}\end{array}$ & $\begin{array}{l}124 \\
\pm 8 \\
131 \\
\pm 9\end{array}$ & $\begin{array}{l}127 \\
\pm 10 \\
130 \\
\pm 9\end{array}$ & $\begin{array}{l}122 \\
\pm 8 \\
129 \\
\pm 7\end{array}$ & $\begin{array}{l}131 \\
\pm 9 \\
169 \\
\pm 7\end{array}$ & $\begin{array}{l}120 \\
\pm 11 \\
126 \\
\pm 9\end{array}$ \\
\hline $\begin{array}{l}\text { Left ventricular } \\
\text { end-diastolic pressure } \\
\text { (mmHg) }\end{array}$ & $\begin{array}{l}\mathrm{M} \\
\mathrm{NaCl}\end{array}$ & $\begin{array}{l}6.8 \\
\pm 1.2 \\
5.4 \\
\pm 0.9\end{array}$ & $\begin{array}{l}3.2 \\
\pm 0.7^{c} \\
6.2 \\
\pm 0.5\end{array}$ & $\begin{array}{l}3.8 \\
\pm 0.8 c \\
5.8 \\
\pm 0.7\end{array}$ & $\begin{array}{l}6.5 \\
\pm 1.1 \\
13.7 \\
\pm 1.2^{c}\end{array}$ & $\begin{array}{l}7.2 \\
\pm 1.2 \\
11.2 \\
\pm 0.8 \mathrm{c}\end{array}$ \\
\hline $\begin{array}{l}\mathrm{DP} / \mathrm{d} t_{\max } \\
(\mathrm{mmHg} / \mathrm{sec})\end{array}$ & $\begin{array}{l}\mathrm{M} \\
\mathrm{NaCl}\end{array}$ & $\begin{array}{l}2180 \\
\pm 201 \\
2431 \\
\pm 186\end{array}$ & $\begin{array}{l}2240 \\
\pm 199 \\
2601 \\
\pm 201\end{array}$ & $\begin{array}{r}2016 \\
\pm 167 \\
2379 \\
\pm 154\end{array}$ & $\begin{array}{l}2007 \\
\pm 137 \\
1421 \\
\pm 141\end{array}$ & $\begin{array}{l}1970 \\
\pm 211 \\
1640 \\
\pm 134 \mathrm{c}\end{array}$ \\
\hline $\begin{array}{l}\text { ST-segment elevation } \\
(\mathrm{mV})\end{array}$ & $\begin{array}{l}\mathrm{M} \\
\mathrm{NaCl}\end{array}$ & $\begin{array}{l}34 \\
\pm 6 \\
42 \\
\pm 3\end{array}$ & $\begin{array}{l}31 \\
\pm 4 \\
40 \\
\pm 6\end{array}$ & $\begin{array}{l}35 \\
\pm 9 \\
52 \\
\pm 4\end{array}$ & $\begin{array}{l}40 \\
\pm 5 \\
88 \\
\pm 4\end{array}$ & $\begin{array}{l}37 \\
\pm 8 \\
83 \\
\pm 6\end{array}$ \\
\hline $\begin{array}{l}\text { Mean coronary blood } \\
\text { flow }(\mathrm{ml} / \mathrm{min})\end{array}$ & $\begin{array}{l}\mathrm{M} \\
\mathrm{NaCl}\end{array}$ & $\begin{array}{l}48.1 \\
\pm 3.2 \\
40.0 \\
\pm 4.1\end{array}$ & $\begin{array}{l}36.2 \\
\pm 4.1 \mathrm{c} \\
42.6 \\
\pm 3.0\end{array}$ & $\begin{array}{l}44.3 \\
\pm 2.2 \\
39.6 \\
\pm 3.2\end{array}$ & $\begin{array}{l}11.8 \\
\pm 1.5 \mathrm{~d} \\
0 \\
\pm 1.1 \mathrm{~d}\end{array}$ & $\begin{array}{l}0 \\
\pm 3.2^{d} \\
0 \\
\pm 0 d\end{array}$ \\
\hline $\begin{array}{l}\text { Coronary resistance } \\
\left(\mathrm{mmHg} \times \min \times \mathrm{ml}^{-1}\right)\end{array}$ & $\begin{array}{l}\mathrm{M} \\
\mathrm{NaCl}\end{array}$ & $\begin{array}{l}2.5 \\
\pm 1.0 \\
3.0 \\
\pm 0.6\end{array}$ & $\begin{array}{l}2.2 \\
\pm 0.8 \\
2.8 \\
\pm 0.8\end{array}$ & $\begin{array}{l}2.7 \\
\pm 0.7 \\
3.0 \\
\pm 0.8\end{array}$ & $\begin{array}{l}- \\
-\end{array}$ & $\begin{array}{l}- \\
-\end{array}$ \\
\hline
\end{tabular}

a Minutes or hours after $0.10 \mathrm{mg} / \mathrm{kg}$ molsidomine $(\mathrm{M})$ and saline $(\mathrm{NaCl})$ administration.

b Values are given as mean \pm S.E.M. of 8 experiments in the molsidomine and of 6 experiments in the saline group.

c Significantly different vs. control with $P<0.05$.

d Significantly different vs. control with $P<0.01$. 


\section{TABLE 2}

Effects of molsidomine on thrombus formation, infarct size, and thrombus weight. Data are given as the mean \pm S.E.M. of 8 experiments in the molsidomine group and 6 experiments in the saline group. LCX $=$ left circumflex coronary artery.

\begin{tabular}{lll}
\hline Parameter & Saline & Molsidomine \\
\hline
\end{tabular}

Thrombus formation

(hours, after compound administration)

$$
\begin{array}{llll}
3.1 \pm 0.4 & 3.8 \pm 0.3^{\mathrm{a}} \\
28 & \pm 2.0 & 14 & \pm 3.0^{\mathrm{b}} \\
58 & \pm 14 & 18 & \pm 3.0^{\mathrm{c}} \\
32 & \pm 4.0 & 14 & \pm 0.8^{\mathrm{a}}
\end{array}
$$

Infarct size :

(1) \% left centricular mass

(2) \% LCX area-at-risk

$28 \pm 2.0 \quad 14 \pm 3.0^{\mathrm{b}}$

LCX thrombus mass

(mg, wet weight)

a Significantly different vs. control with $P<0.05$.

b Significantly different vs. control with $\mathrm{P}<0.02$.

c Significantly different vs. control with $P<0.01$.

coronary resistance did not change in either group until the time of vessel occlusion. The results shown in table 2 summarize the effects of molsidomine on infarct size and thrombus wet weight. Compared to controls drug treatment resulted in significantly reduced ischemia when related to left ventricular weight or to the LCX area-at-risk. Drug-treatment also reduced development of LCX thrombus mass, and examination of the vessel in molsidominetreated animals revealed minor thrombus adherence and intima necrosis.

\section{Discussion}

The results presented in this report demonstrate marked antithrombotic properties of molsidomine in an in-vivo model of coronary artery thrombosis. The model simulates human coronary artery thrombus formation as intimal injury produced by low amperage electrical stimulation of the LCX induced platelet adhesion and secondary recruitment of platelets to form aggregates (Romson et al., 1980a) similar to morphology and composition of humen coronary artery thrombi.
Although coronary blood flow decreased after administration of molsidomine concomitant to the fall in perfusion pressure, an improvement of coronary blood supply to jeopardized tissues can be assumed from the smaller ultimate ischemic regions.

In recent experiments (Schaper, unpublished results) with canine hearts perfused at constant aortic pressure large epicardial coronary arteries dilated. Such an event may not increase coronary blood flow in the unaffected area of the coronary bed but it may serve as an important mechanism for improving coronary flow to an ischemic region of the myocardium probably via collaterals. At the same time there is a dose-dependent decrease in blood pressure (Fiedler and Scholtholt, 1978) which is not accompanied by reflex increase in heart rate or contractility. Thus, it seems likely that a dilatation of the coronary bed, as indicated in the present study by a minor decrease in coronary resistance (table 1) together with an increase in regional myocardial blood flow (Scholtholt et al., 1978) and the fall in myocardial work and oxygen consumption (Gross and Gharaibeh, 1980) resulted in a significant protection of the ischemic myocardium with respect to viability of jeopardized tissues. The significance of the present study lies in the fact that ischemic heart disease represents one major health problem and is a leading cause of death and morbidity. Current therapy with agents such as nitrates, $\beta$-adrenergic receptor blocking agents, and slow calcium channel blocking drugs, although effective in a large percentage of such patients, has not been without difficulty. Thus, the need for new drugs with mechanisms which compliment the actions of existing agents by additional mode of actions is very much in demand. The initial clinical trials with molsidomine suggested that it may be valuable for treatment of the ischemic heart. In addition to the aforementioned hemodynamic, extracardiac effects of the drug and influences on regional myocardial blood flow, there may be a direct effect on platelet aggregation and thrombus forma- 
tion in vivo which prevents coronary artery narrowing and/or occlusion as one primary cause for myocardial ischemia.

\section{References}

Fiedler, V.B. and J. Scholtholt, 1978, Haemodynamic effects of molsidomine, Arzneim. Forsch. 28, 1605.

Gross, G.J. and M. Gharaibeh, 1980, Effect of molsidomine on coronary collateral blood flow in acute myocardial ischemia, European J. Pharmacol. 67, 111.

Holtz, J., E. Bassenge and A. Kolin, 1978, Hemodynamic and myocardial effects of long-lasting venodilation in the conscious dog: analysis of molsidomine in comparison with nitrates, Basic Res. Cardiol. 73, 469 .

Majid, P.A., P.J.F. DeFeyter, E.E. Van der Wall, R. Wardeh and J.P. Roos, 1980, Molsidomine in the treatment of patients with angina pectoris. Acute hemodynamic effects and clinical efficacy, N. Engl. J. Med. 302, 1.

Romson, J.L., L.R. Bush, D.W. Haak and B.R. Lucchesi, 1980a, The beneficial effects of oral ibuprofen on coronary artery thrombosis and myocardial ischemia in the conscious dog, J. Pharmacol. Exp. Ther. 215, 271.

Romson, J.L., D.W. Haack and B.R. Lucchesi, 1980b, Electrical induction of coronary artery thrombosis in the ambulatory canine: a model for in vivo evaluation of anti-thrombotic agents, Tromb. Res. 17,841 .

Scholtholt, J., V.B. Fiedler and M. Keil, 1978, Die Wirkung von Molsidomin und Nitroglycerin auf die regionale Durchblutung des normalen und akut-ischämischen Myokards, Arzneim. Forsch. 28, 1619.

Slany, J., K. Silberbauer, H. Sinzinger and Chr. Punzengruber, 1981, Einfluss von Molsidomin auf die Thrombozytenaggregation und das Prostaglandinsystem, Z. Kardiol. (Abstrakt) 70, 269. 